\title{
Moisture condition of building materials in different operating conditions
}

\author{
Vladimir G. Gagarin \\ Research Institute of Mechanics \\ Lomonosov Moscow State University \\ Russia \\ 1, Michurinsky Pr., Moscow, 119192
}

\author{
Pavel P. Pastushkov \\ Research Institute of Mechanics \\ Lomonosov Moscow State University \\ Russia \\ 1, Michurinsky Pr., Moscow, 119192
}

\author{
Natalia V. Pavlenko \\ Department of Material Science and Material Technology \\ Belgorod State Technological University named after \\ V.G. Shukhov \\ BSTU named after V.G. Shukhov \\ Russia \\ 46, Kostukov St., Belgorod, 308012 \\ 9103638838@mail.ru
}

\author{
Alexander S. Kubenin \\ Research Institute of Mechanics \\ Lomonosov Moscow State University \\ Russia \\ 1, Michurinsky Pr., Moscow, 119192
}

\begin{abstract}
The definition of the concepts of theoretical and operating moisture of building materials is given in the paper. The estimated moisture is determined. To determine operating moisture, the analysis methods are used. The issues with the estimated moisture based on field studies are presented. Methods of calculating moisture of building materials by sorption isotherm are proposed. Literature and regulations on the use of mathematical methods for calculating moisture conditions are described in the article. Links to the relevant regulations to determine the procedures necessary for numerical calculations of the moisture properties of building materials are provided in the paper. A new formula for operating moist calculation basing on the results of field studies of moisture in the enclosing structures is presented in the article. The article describes the results of fullscale, numerical and laboratory studies to determine the estimated moisture of building materials. Discrepancy of field study results and laboratory data is revealed; thereby, inadequacy of the method of calculated moisture of building materials by sorption isotherm is proved. A good convergence of results of numerical and field investigations, which show the validity of application of the mathematical method when determining the estimated moisture content in building materials, are presented.
\end{abstract}

Keywords - calculated humidity, operating humidity, building materials, field studies, moisture behavior, unsteady calculation method.

\section{INTRODUCTION}

In the course of the building operation, the moisture condition of enclosing structure materials varies depending on the design features, material properties, temperature and humidity in the facilities, as well as the climate of the region where the construction takes place [1-5]. Serviceability of the enclosing structures of a building is determined by the moisture conditions. It directly affects both the thermal properties of enclosing structures [6] and the energy efficiency of applied materials.

Calculations of the moisture conditions make it possible to solve various problems related to thermal physics. A stationary method for moisture condition estimation [7] allows us to check the construction in terms of the inadmissibility of moisture accumulation in it during the annual operation period, as well as moisture limitation for the period with the negative average monthly outside temperatures. Calculations made on the basis of non-steady methods [8,9] make it possible to acquire not only qualitative estimates of the moisture state of enclosing structures, but also specific quantitative results of the moisture content in the layers of building materials. The main calculation result of the moisture condition of enclosing structures on the basis of non-steady methods would be the distribution of moisture along the thickness of the structure at any time after the beginning of the operation of the building. Using this result, it is possible to get answers to particular problems, including the determination of the moisture value of building materials.

When designing the enclosing structures of buildings, one of the main characteristics would be the design moisture of building materials under various operating conditions. The results of the work were obtained during the studies carried out in various climatic zones on the territory of the Russian Federation, which in accordance with the construction norms and regulation (SNiP) 23-02-2003 on "Thermal protection of buildings" is divided into operating conditions A and $\mathrm{B}$. The 
characteristics of the calculated moisture are used in thermal and technical calculations, the results of which solve the following issues: the choice of the type of thermal insulation material for a multilayer structure, necessary thickness of a masonry for a single-layer structure and the conformity of construction to modern construction norms. That is why the assignment of the calculated value of moisture causes many questions and disputes among manufacturers and designers of building materials. This article is devoted to the disclosure of the concept of the calculated moisture of building materials and the description of methods for its determination.

The calculated moisture of building material is the operating moisture of the material for generalized operating conditions $\mathrm{A}$ or $\mathrm{B}$. The operating conditions are assigned for specified moisture and humidity conditions in the room according to the code of rules (CR) 50.13330.2012 on the updated version of building codes and regulations "SNiP 2302-2003 Thermal protection of buildings" [10].

Operating moisture is the equilibrium moisture content of material in the enclosure with respect to the humidity factors of the internal and external environment that affect it during operation. The moisture content in the material becomes equilibrium after passing through the construction stage and the subsequent post-construction stage when the structure is operated in the quasi-stationary (remains unchanged in the time interval of one day; however, it periodically changed during the year) humidity mode. The duration of this establishment varies considerably and depends on the initial (construction / technological) moisture content of material, composition of the structure and climate of the region where the construction takes place.

\section{METHODS}

To determine the operating moisture, field studies were applied. However, the results of such studies, even for the same type of construction and under the same climatic conditions can vary greatly [11]. To assign the value of calculated moisture under operation conditions A and B in the table of thermal and technical indicators of the code of regulations 50.13330.2012, a huge database of field studies in different climatic zones for the statistical analysis, as well as expert assessments were used. At the moment, to carry out thermal and technical calculations, the obtained data are the main reference material.

As it was mentioned above, in order to assign the calculated moisture for each type of material basing on the field studies, the inspection results of enclosing structures in different regions are needed; therefore, the method of assigning the calculated moisture is time-consuming and costly as well. In order not to waste time and money on the studies, some companies and specialists prefer using thermal conductivity of materials in a dry state rather than using calculated thermal conductivity (depending on the calculated moisture) for thermal and technical calculation. This approach is not an advanced one and does not allow improving the enclosing structures from the point of view of their temperature and humidity state; therefore, the structures during their operation will not have necessary heat-protective properties and durability [12].
It is scientifically justified to use the assignment method of calculated moisture basing on the sorption isotherm when the value of the calculated moisture under operating conditions A is taken to be equal to the value of the sorption moisture of the material at a relative humidity of $80 \%$; and respectively, under operating conditions B at a relative humidity of 97\% [13]. Several indicators are usually taken into account during the humidification of building materials: vapor permeability, water vapor sorption, and capillary absorption. The moisture condition of the enclosing structures varies depending on the structure and properties of material, the microclimate in the room and the climate of the region where the construction takes place, which results in some changes in thermal characteristics of the enclosing structures [14].

\section{MAIN PART}

The method of determining values of operational moisture basing on the results of numerical calculations of the moisture condition of enclosing structures using non-stationary mathematical models [10] is fundamentally different. Unlike simplified methods, non-stationary numerical methods allow one to simulate the operation of construction taking into account any significant mechanism of heat and moisture transfer in the structure, as well as changes in climatic parameters. Non-stationary calculation methods of moisture condition have been known since 1930 of the $20^{\text {th }}$ century [15, 16]. At present, when designing modern buildings, the method of mathematical modeling of both temperature and humidity states of enclosing structures is applied.

To carry out calculations based on the mathematical model proposed, the characteristics of the boundary conditions are necessary, including the temperature and relative humidity of the outdoor air, the characteristics of the enclosing structure, i.e. the composition and thickness of the layers of materials, as well as heat and moisture characteristics of construction material: specific heat, thermal conductivity, vapor permeability. To carry out comprehensive analysis and obtain reliable results, in addition to standard heat and moisture characteristics, a sorption isotherm is required, which is determined in accordance with the standard procedure (according to the State Standard (GOST) 24816-2014 "Building materials. Method for determining the equilibrium sorption moisture"). Besides, the conductivity and capillary absorption is needed for the analysis. The methods for determining these characteristics were previously described.

Autoclaved aerated concrete is currently the most common material used for the outer enclosing structures of the buildings. The last major studies on the moisture condition were conducted for cellular concrete with different heat and moisture characteristics (since then the manufacturing equipment has been completely replaced; technologies and compositions have been changed due to the changes introduced in the thermal protection norms; the grades of reduced density D300 and D400 are more widely used). In this connection, it is necessary to update data on the heat and moisture characteristics of autoclaved aerated concrete. To this end, a number of experimental studies have been carried 
out. The most significant are the results of studies of vapor permeability and sorption of water vapor as for the first time in recent years, the main grades of autoclaved aerated concrete were tested simultaneously according to GOST methods and with the use of special equipment. Besides, for the first time the methods of capillary suction and moisture conductivity were tested and the results of studies were obtained for the samples of modern aerated concrete.

The averaged results of experimental studies of water vapor sorption by the samples of autoclaved aerated concrete of the main grades are presented in Table 1. Tests were carried out according to the GOST 24816-81 procedure.

TABLE I. RESULTS OF SORPTION STUDIES BY SAMPLES OF AUTOCLAVED AERATED CONCRETE

\begin{tabular}{|c|c|c|c|c|c|}
\hline \multirow{2}{*}{$\begin{array}{c}\text { Concret } \\
\text { e grade }\end{array}$} & \multicolumn{5}{|c|}{$\begin{array}{c}\text { Sorption humidity, \%, by weight, } \\
\text { at a temperature of }(\mathbf{2 0} \pm \mathbf{2})^{\circ} \mathbf{C} \text { and } \\
\text { relative air humidity, \% }\end{array}$} \\
\cline { 2 - 6 } & $\mathbf{4 0}$ & $\mathbf{6 0}$ & $\mathbf{8 0}$ & $\mathbf{9 0}$ & $\mathbf{9 7}$ \\
\hline $\mathrm{D} 300$ & 0.102 & 0.36 & 1.9 & 3.15 & 6.3 \\
\hline $\mathrm{D} 400$ & 0.063 & 0.22 & 1.32 & 2.48 & 4.54 \\
\hline $\mathrm{D} 500$ & 0.036 & 0.16 & 1.23 & 2.19 & 4.25 \\
\hline $\mathrm{D} 600$ & 0.021 & 0.083 & 1.1 & 2.08 & 4.00 \\
\hline
\end{tabular}

On the basis of the obtained data, one may conclude that the lower the density of aerated concrete, the greater the sorption. This is due to the greater porosity of cellular concrete with the lower density.

The averaged results of the resistance to vapor permeation and calculation of the coefficient of vapor permeability of the main grades of aerated concrete are presented in Table 2. The tests were carried out according to the GOST 25898-2012 procedure. The thickness of the test sample was $25 \mathrm{~mm}$.

TABLE II. RESULTS OF AERATED CONCRETE VAPOR PERMEATION

\begin{tabular}{|c|c|c|c|}
\hline $\begin{array}{c}\text { Concre } \\
\text { te } \\
\text { grade }\end{array}$ & $\begin{array}{c}\text { Average } \\
\text { sample } \\
\text { density, } \\
\rho, \mathbf{k t} / \mathbf{m}^{3}\end{array}$ & $\begin{array}{c}\text { Resistance } \\
\text { to vapor } \\
\text { permeatio } \\
\mathrm{n}, \boldsymbol{R}_{\mathrm{II}} \\
\mathrm{m}^{2} \cdot \mathbf{h} \cdot \mathrm{Pa} / \mathrm{m} \\
\mathrm{g}\end{array}$ & $\begin{array}{c}\text { Vapor } \\
\text { permeati } \\
\text { on, } \\
\mu, \\
\mathrm{mg} /(\mathbf{m} \cdot \mathbf{h} \cdot \\
\mathbf{P a})\end{array}$ \\
\hline D300 & 330 & 0.198 & 0.126 \\
\hline D400 & 410 & 0.215 & 0.120 \\
\hline D500 & 504 & 0.240 & 0.105 \\
\hline D600 & 634 & 0.268 & 0.095 \\
\hline
\end{tabular}

It is possible to draw the conclusion that the higher the density of aerated concrete, the greater the resistance to vapor permeation and, correspondingly, the lower the permeability coefficient.

Using the obtained current heat and moisture characteristics of aerated concrete, trial calculations of the non-stationary moisture conditions of multilayer enclosing structures in different climate regions where the construction takes place were carried out. The walls from the aerated concrete D400 with a facade system and bonded thermal insulation were investigated using the main types of insulation: mineral wool, molded expanded polystyrene (foam) and extruded polystyrene with an outer thin plaster layer. In the course of the calculations, it was assumed that the temperature and humidity in the room remain constant throughout the year and are equal to $+20^{\circ} \mathrm{C}$ and $55 \%$, respectively. The temperature and relative humidity of the air outside the construction vary. The data for the calculations were taken from CR 131.13330.2012. Updated edition of SNiP 23-01-99* is "Construction climatology".

Based on the calculation results of the moisture conditions of the considered types of the structures, the values of the operating moisture of materials for the climatic conditions of the selected cities where the construction takes place were calculated. Table 3 shows the values of operating moisture of the aerated concrete of grade D400 and effective insulation after a month of maximum moist accumulation. Values for aerated concrete are given for a structure with extruded polystyrene foam.

TABLE III. OPERATING MOISTURE ONE MONTH AFTER THE LONGEST MOIST ACCUMULATION

\begin{tabular}{|c|c|c|c|c|c|c|}
\hline \multirow{2}{*}{$\begin{array}{c}\text { Materia } \\
\mathbf{I}\end{array}$} & \multicolumn{6}{|c|}{ Operating moisture, $\boldsymbol{w}_{3}, \%$} \\
\cline { 2 - 7 } & $\begin{array}{c}\text { Mosc } \\
\text { ow }\end{array}$ & $\begin{array}{c}\text { St. } \\
\text { Petersbu } \\
\text { rg }\end{array}$ & $\begin{array}{c}\text { Ekateri } \\
\text { nburg }\end{array}$ & $\begin{array}{c}\text { Novosi } \\
\text { birsk }\end{array}$ & $\begin{array}{c}\text { Vladiv } \\
\text { ostok }\end{array}$ & $\begin{array}{c}\text { Krasno } \\
\text { dar }\end{array}$ \\
\hline $\begin{array}{c}\text { Aerated } \\
\text { concrete } \\
\text { D400 }\end{array}$ & 3.18 & 3.13 & 3.47 & 3.56 & 2.93 & 218 \\
\hline $\begin{array}{c}\text { Mineral } \\
\text { wool }\end{array}$ & 0.79 & 0.87 & 0.80 & 1.11 & 0.53 & 0.75 \\
\hline $\begin{array}{c}\text { Plastic } \\
\text { foam }\end{array}$ & 2.59 & 2.62 & 3.58 & 4.49 & 2.30 & 1.82 \\
\hline XPS & 0.32 & 0.35 & 0.24 & 0.28 & 0.23 & 0.38 \\
\hline
\end{tabular}

With the help of the obtained experimental data, it is possible to do further calculations of non-stationary moisture conditions of enclosing structures using autoclaved aerated concrete. The numerical calculation results presented in this paper can be used for calculation of the effective thermal conductivity of masonries of aerated concrete blocks, as well as for the calculation of indicators of energy efficiency of thermal insulation materials.

A set of works was performed to determine the thermal and physical parameters of autoclaved aerated concrete with the range of grades in density from $100 \mathrm{~kg} / \mathrm{m}^{3}$ to $600 \mathrm{~kg} / \mathrm{m}^{3}$. Based on the results of the studies, the thermal conductivity was established in the dry state at an average temperature of $25^{\circ} \mathrm{C}, \lambda 0, \mathrm{~W} /(\mathrm{m} \bullet \mathrm{oC})$ and the increment of thermal conductivity by $1 \%$ of moisture, $\Delta \lambda, \mathrm{W} /(\mathrm{m} \bullet \mathrm{oC} \bullet \%)$. Based on the results obtained, the coefficient of thermal and technical quality (TTQ) was calculated: $1 / \%$. Table 4 presents the averaged results of these studies. 
TABLE IV. RESULTS OF THERMAL AND PHYSICAL INDICATORS OF AERATED CONCRETE

\begin{tabular}{|c|c|c|c|c|}
\hline Grade & $\begin{array}{c}\text { Average } \\
\text { sample } \\
\text { density, } \rho, \\
\mathrm{kg} / \mathrm{m}^{3}\end{array}$ & $\begin{array}{c}\text { Thermal } \\
\text { conductivity in } \\
\text { dry condition, } \\
\lambda_{0}, \mathrm{~W} /\left(\mathbf{m}^{\circ} \cdot{ }^{\circ} \mathrm{C}\right)\end{array}$ & $\begin{array}{c}\text { Moisture } \\
\text { increase by } \\
1 \%, \Delta \lambda, \\
\mathrm{W} /\left(\mathbf{m} \cdot{ }^{\circ} \mathbf{C} \cdot \%\right) \\
\end{array}$ & $\begin{array}{c}\text { TTQ, } \\
\eta, 1 / \%\end{array}$ \\
\hline D100 & 112 & 0.049 & 0.002 & 0.043 \\
\hline D300 & 316 & 0.091 & 0.004 & 0.043 \\
\hline D400 & 416 & 0.111 & 0.005 & 0.045 \\
\hline D500 & 494 & 0.130 & 0.006 & 0.044 \\
\hline D600 & 616 & 0.158 & 0.007 & 0.044 \\
\hline
\end{tabular}

Figure 1 shows the dependence of the thermal conductivity in the dry state on the density approximated by the straight line. The red dots indicate thermal conductivity of aerated concrete (CR 50.13330).

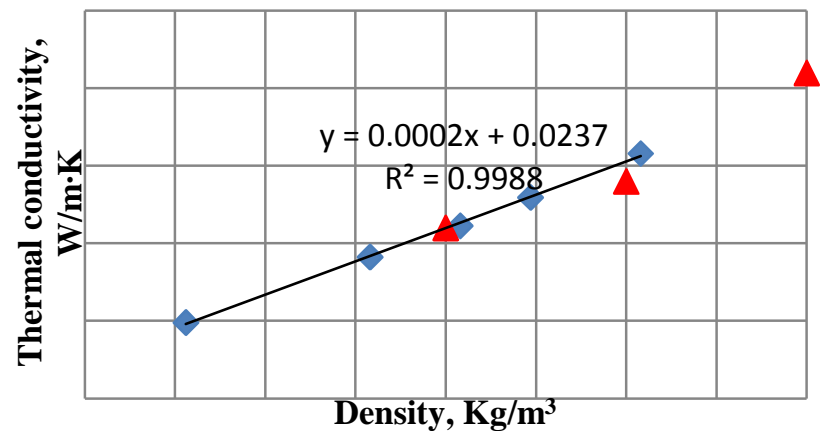

Fig.1. Dependence of thermal conductivity on density

It can be seen that the experimental data obtained are well represented as a linear dependence (the experimental points lie exactly on the approximating straight line). The obtained dependence of thermal conductivity in the dry state is described by the equation (provided that at a density of 0 $\mathrm{kg} / \mathrm{m}^{3}$, thermal conductivity is equal to thermal conductivity of the air in a calm state of $\left.0.026 \mathrm{~W} /\left(\mathrm{m} \cdot{ }^{\circ} \mathrm{C}\right)\right)$ :

$$
\lambda_{0}=0.00021 \rho+0.026 \mathrm{~W} /\left(\mathrm{m} \cdot{ }^{\circ} \mathrm{C}\right)
$$

According to Fig. 1, it can be concluded that the data presented in CR 50.13330 for thermal conductivity in dry state for aerated concrete in the density range from $400 \mathrm{~kg} / \mathrm{m}^{3}$ to $800 \mathrm{~kg} / \mathrm{m}^{3}$ are close to the dependence constructed on the basis of the experimental results. However, equation (1) allows us to find thermal conductivity of aerated concrete with much greater accuracy, as well as for grades with the density below $400 \mathrm{~kg} / \mathrm{m}^{3}$.

The TTQ value for each type of material is almost the same. The obtained dependence confirms this result for autoclaved aerated concrete of modern manufacture.
According to the studies, the value of TTQ for aerated concrete is $(1 / \%)$. This value can be used to find the calculated thermal conductivity, $\lambda, \mathrm{W} /(\mathrm{m} \cdot \mathrm{oC})$ using the following formula:

$$
\lambda=\lambda_{0}+\Delta \lambda \cdot w_{\ni}=\lambda_{0}\left(1+\frac{\Delta \lambda}{\lambda_{0}} \cdot w_{\ni}\right)=\lambda_{0}\left(1+\eta \cdot w_{\ni}\right)
$$

where $\mathrm{w}_{\ni}$ is the operating moisture of the material by weight, $\%$.

If, using formula (2), one calculates the TTQ according to the data from the table of thermal and technical indicators (Appendix T of CR 50.13330) and compare them with the found values, it can be concluded that for a grade with the density of $400 \mathrm{~kg} / \mathrm{m}^{3}$ the values in CR 50.13330 are underestimated (TTQ is approximately 0.03 ), and for a grade with the density of $600 \mathrm{~kg} / \mathrm{m}^{3}$ are, on the contrary, overestimated (0.07). In this context, the average TTQ value, which is equal to 0.04 correlates with the data from GOST 31359-2007 on "Cellular concretes of autoclaved curing. Operating conditions". However, in this standard, for a grade with the density of $600 \mathrm{~kg} / \mathrm{m}^{3}$, the calculated thermal conductivities are indicated with the error: for moisture of $4 \%$, TTQ is 0.036 and for moisture of $5 \%-0.061$, i.e. the linear dependence of thermal conductivity on humidity is violated.

Thus, as a result of the conducted studies, a linear dependence of thermal conductivity in the dry state on the density of autoclaved aerated concrete was identified. According to the density of aerated concrete, the TTQ value of the investigated grades is approximately the same and is equal to $0.04(1 / \%)$. The obtained data on the values of thermal and physical parameters can be used for assignment and analysis of design values for thermal conductivity of aerated concrete, as well as for updating and issuing new regulatory documents in the field of thermal protection of buildings and production of aerated concrete.

In spite of the fact that from the theoretical point of view the mathematical model fully describes the operation of the construction, the results of any numerical studies require comparisons with the results of field studies [17]. Therefore, in parallel to several series of numerical calculations [10], the team of authors carried out a number of full-scale surveys of different types of enclosing structures in different climatic zones (Moscow, Tver, St. Petersburg, Murmansk, Novosibirsk, Petropavlovsk-Kamchatsky). The wide geography of field studies allows applying the results obtained to other countries located in different climatic zones. Samples of materials were taken from the operating enclosing structures taking into account their thickness; then the moisture of each sample was determined with the help of the thermal and gravimetric method in laboratory conditions. As a result, the distribution of moisture within the structure was established, as well as the values of the operating moisture of materials were included in its composition. For this purpose, a new method for determining the operating moisture content of the material (structural layer) was proposed based on the 
principle of equality of thermal resistance of the construction layer in case of unevenly distributed humidity and thermal resistance with medium (operating) moisture. Using this equality, a formula to calculate the operating moisture was obtained:

$$
w_{3} \approx \frac{\delta}{\sum_{1}^{n} \frac{\Delta x_{i}}{\frac{1}{\eta}+w_{i}}}-\frac{1}{\eta}
$$

where $w^{i}$ [dublv i] is the material moisture content within $\mathrm{i}$ cross-section of construction, width [delta iks i];

$\delta$ [delta] is the width of the material layer, meter;

$\eta$ [eta] is the coefficient of thermal and technical quality (TTQ), $1 / \%$.

To check the applicability of procedure for assigning the calculated moisture content of materials on the sorption isotherm, water vapor sorption was studied according to State Standard (GOST) 24816-2014 [13, 18] after determining the moisture content of samples, taken from the samples of materials. Sorption of water vapor of building products is used to study issues related to the moisture state of materials in structures. The characteristic of sorption humidity is the ratio of the moisture mass absorbed by the material from the air to the mass of dry material expressed as a percentage.

The values of the operating moisture content of materials obtained on the basis of the results of field studies and numerical calculations, as well as the sorption of water vapor at a relative air humidity of $80 \%$ and $97 \%$ of samples of captured materials are presented in Table 4.

TABLE V. RESULTS OF FIELD, NUMERICAL AND LABORATORY STUDIES

\begin{tabular}{|c|c|c|c|c|c|}
\hline \multirow[b]{2}{*}{ Material } & \multirow{2}{*}{$\begin{array}{c}\text { City } \\
\text { (operating } \\
\text { conditions) }\end{array}$} & \multicolumn{2}{|c|}{$\begin{array}{c}\text { Operating } \\
\text { moisture, \% }\end{array}$} & \multicolumn{2}{|c|}{$\begin{array}{c}\text { Sorption } \\
\text { humidity, } \% \text {, } \\
\text { by mass at } \\
\text { relative } \\
\text { humidity, } \%\end{array}$} \\
\hline & & $\begin{array}{c}\text { Field } \\
\text { studies }\end{array}$ & $\begin{array}{l}\mathrm{Nu} \\
\mathrm{mer} \\
\text { ical } \\
\text { calc } \\
\text { ulat } \\
\text { ion }\end{array}$ & 80 & 97 \\
\hline Mineral wool & \multirow{2}{*}{$\begin{array}{l}\text { Novosibirsk } \\
\text { (A) }\end{array}$} & 1.13 & 0.95 & 0.36 & 1.07 \\
\hline Polystyrene foam & & 3.13 & 3.25 & 0.05 & 0.2 \\
\hline Mineral wool & \multirow{3}{*}{$\begin{array}{l}\text { St. Petersburg } \\
\text { (B) }\end{array}$} & 0.95 & 0.94 & - & - \\
\hline Polystyrene foam & & 2.27 & 2.62 & - & - \\
\hline $\begin{array}{c}\text { Aerated concrete } \\
\text { D400 }\end{array}$ & & 8.8 & 8.35 & 4.65 & 5.23 \\
\hline Loam brick & Moscow (B) & 4.75 & - & 0.4 & 1.1 \\
\hline
\end{tabular}

As it was described above, the method for assigning the calculated moisture on the sorption isotherm is to equate the sorption humidity of $80 \%$ to the calculated one under operating conditions A, and of $97 \%$ - under operating conditions B. As is seen from Table 2, there is no such coincidence, moreover in some cases these values differ by an order of magnitude. This is due to the fact that, in addition to the moisture sorption from the air, building materials undergo other kinds of humidification, such as vapor and liquid inside the structure, oblique rain, etc. [19]. Therefore, it would be wrong not to take into account these mechanisms and assign the calculated moisture content of materials only basing on the values of moisture sorption. Besides, Table 4 shows that the discrepancy between the results of field studies and numerical calculations does not exceed $15 \%$, which is a good result.

\section{CONCLUSION}

Thus, basing on the results of field, numerical and laboratory studies, the authors established that the design moisture of building materials is not based only on the values of sorption humidity [13]. The method employed to determine the calculated moisture content of building materials by performing numerical calculations of the moisture conditions using a non-stationary method [10] followed by data correction based on the results of the series of field studies in different climatic zones of construction gives reliable values.

\section{Acknowledgment}

The work was supported by the Ministry of Education and Science of the Russian Federation (Agreement No. 14.576.21.0079; project ID RFMEFI57614X0079).

The work is carried out in the framework of the Strategic Development Program on the basis of Belgorod State Technological University named after V.G. Shukhov.

The equipment of the High Technology Center, BSTU was used to carry out different kinds of studies.

\section{References}

[1] M. Aksoezen, M. Daniel, U. Hassler, N.I. Kohler, "Building age as an indicator for energy consumption," Energy and Buildings, vol.87, pp.74-86, 2015.

[2] A. A. Mamontov, V. P. Yartsev, S. A. Strulev, "The analysis of moisture of various thermal insulations in the constructions of buoldings during the heating season," Academia. Architecture and constructin, 4, pp. 117119, 2013.

[3] B. P. "Jelle Traditional, state-of-the-art and future thermal building insulation materials and solutions - Properties, requirements and possibilities," Energy and Buildings, vol. 43, pp. 2549-2563, 2011.

[4] G. I. Grinfeld, P. D. Kuptaraeva, "Masonring from the autoclaved aerated concrete with uoter thermal insulation. Peculiarities of moister conditions in the beginning of the operating period," Engineering journal, 8, pp.41-50, 2011.

[5] E. M. Chernyshov, G.S. Slavcheva, "Moisture condition and regularity of construction properties of construction materials," Academia. Architecture and construction, 4, pp. 70-77, 2007.

[6] M.S. Al-Homoud, "Performance characteristics and practical applications of common building thermal insulation materials," Building and Environment, vol. 40, pp. 353-366, 2005.

[7] CR 50.13330.2012. Updated eddition of SNiP 23-02-2003 "Thermal protection of buildings".

[8] A .G. Perehozhentsev, I.Yu. Gruzdo, "Study of the moisture diffusion in the porous building materials," Vestnik Volgogad State University of Archtecture and Civil Engineering, vol., 35(54), pp. 116-120, 2014.

[9] S. V. Kornienko, "Thermal and moisture condition and thermal protective properties of the constructions with he booundary areas," Vestnik Volgogad State University of Archtecture and Civil 
Engineering. Ser.: Construction and architecture, vol.35(54), 2014, pp. 62-69. (in Russian).

[10] P.P. Pastushkov, N.V Pavlenko, E.V. Korkina, "The use of a nominal definition operational humidity insulation materials," Construction and reconstruction, 4 (60), pp. 168-172, 2015.

[11] B.F. Vasiliev, "Field studies of temperature and humidity conditions of residential buildings," Moscow: GOS. publishing house of literature on construction and architecture, 1957, p. 214.

[12] V.V. Strokova, S.Y. Lozovaja, L.N. Solovyova, Y.N. Ogurtsova, Prediction of properties of structural insulating concrete-based granular nanostructured filler. Bulletin of the Belgorod State Technological University named after. V.G. Shukhov, 1, pp. 15-19, 2011.

[13] V.G. Gagarin, P.P. Pastushkov, N.A. Reutova To the question about the purpose of the estimated moisture content of building materials on the sorption isotherm. Construction and reconstruction, 4 (60), pp. 152-155, 2015

[14] V.V. Strokova, V.M. Vorontsov, A.V. Mospan, A.V. Maximov, "Structural honeycomb wall materials with low thermal conductivity on the basis of active granular aggregates," Bulletin of the Belgorod State Technological University named after V.G. Shoukhov, 1, pp. 42-46, 2010

[15] K.F. Fokin, "The calculation of the sequential wetting of materials in the exterior fencing: the problems of building physics in design," M.: Stroyizdat, 1941, pp. 2-18.

[16] Guidance on the calculation of moisture conditions of building envelopes, Moscow. Strojizdat, 1984, p. 168

[17] S.A. Isaev, S.V. Guvernuk, M.A. Zubin, Yu.S. Prigorodov, "Numerical and physical modeling of a low-velocity air flow in a channel with a circular vortex cell, "Journal of Engineering Physics and Thermophysics, 73(2), p. 337, 2000.

[18] I.Y. Kiselev, "Method of calculation of equilibrium moisture sorption of building materials," Vestnik MGSU, 3-2, p. 92, 2011.

[19] M.I. Kozhukhova, V.V. Strokova, K.S. Sobolev, "Features hydrophobic fine concrete surfaces," Bulletin of the Belgorod State Technological University named after V.G. Shukhov, 4, pp. 33-35, 2014. 